\title{
SEVENTY YEARS SINCE THE ESTABLISHMENT OF THE SKOPJE MILITARY HOSPITAL, 1944-2014
}

\author{
Doncho Donev $^{1}$, Ilija Gligorov ${ }^{2}$, Andreja Naumovski \\ ${ }^{1}$ Institute of Social Medicine, Faculty of Medicine, Ss. Cyril and Methodius University, Skopje, \\ R. Macedonia \\ ${ }^{2}$ Pensioner, independent researcher
}

Corresponding Author: Doncho Donev, MD, PhD, Professor, Institute of Social Medicine, Faculty of Medicine, Ss Cyril and Methodius University, MKD-Skopje, R. Macedonia. Tel. +389 (0)2 32985 80; Fax. +389 (0)2 3298582 , E-mail: dmdonev@gmail.com

\begin{abstract}
Aim: To present the phases and activities over the period of the existence and work of the Military Hospital in Skopje, from its establishment in 1944 to its transformation on 01.01.2010.

Methods: A retrospective study based on available archive materials, encyclopaedias and other sources of information and review of the relevant literature, and personal experiences, observations and memories of the authors and others.

Results: During the War of $1941 \pm 1945$, the larger military units formed hospitals. On 15.11.1944, the hospital of the Headquarters of the People's Liberation Army and Partisan Detachments of Macedonia was moved from the village Gorno Vranovci to Skopje. The Military Hospital in Skopje received the status of permanent hospital of the 5th Army, and from 1945 \pm 1963 worked at the "Crescent" facility. After the earthquake in 1963, due to damage, it was partly moved to the hospital in Nish, and partly dispersed in pavilions. In 1971 a new military medical complex was put into operation, in which most belonged to the Military Hospital in Skopje. Until 1992 the military sanitation service was under the command of the then Yugoslav People's Army, and then was under the jurisdiction of the Ministry of Defence of R. Macedonia. From 10.04.1992 to 2.06.1992 it served as a Military Hospital of the Army of R. Macedonia and then as the "Centre of Military Health Institutions" until 26.10.2001. Then it was renamed the Military Hospital of the Army of R. Macedonia until March 2008, when converted to the Ministry of Defence as "Military Health Service \pm Military Hospital". On 01.01.2010 the Military Hospital was reshaped into: PHI Eighth of September City General Hospital, Skopje, and the Military Medical Centre.

Conclusion: The Military Hospital in Skopje over the period of its existence has been one of the key specialist-consultative and hospital facilities in the health system in R. Macedonia for providing health care to military beneficiaries and the civilian population.
\end{abstract}

Key words: Military hospital, hospitals, secondary health care, hospital treatment, Republic of Macedonia.

\section{Introduction}

Through the centuries many armies have passed over the territory of Macedonia, which had its own health-sanitation service including hospitals. The health of the troops is vital in peacetime and in wartime. Large modern armies have medical units and facilities under their command. Smaller armies $\uparrow$ planning and orga- nizing of health care relies on the health facilities in the territory. The basic functions of health sanitation support are planning, organizing and implementation of: preventive health care, curative care of the injured and sick, sanitary supplies, education and training. After the liberation (1944) in R. Macedonia, besides the Skopje Military Hospital regional military hos- 
pitals worked in Bitola, Shtip, Kumanovo, Prilep and Strumica, with a total capacity of 1500 beds.

The new military force in R. Macedonia started its creation, in the liberation war from 1941 to 1945 , by forming units of the People's Liberation Army (NOV) and Partisan Detachments of Macedonia (POM). The Macedonian army, represented by the partisans and then regular units, treated their sick and wounded soldiers first in secret shelters in the houses of supporters and collaborators and even in the medical facilities that were under the control of the occupier. In parallel with the formation of larger units of the regular army, an organized military medical service was formed and some hospitals were organized in the brigades, divisions and corps [1].

\section{Establishment and development of the Military Hospital in the period 1944-1963}

After the liberation, the Headquarters of NOV and POM made the decision to set up a military hospital in Skopje with the personnel and facilities from the partisan hospital in Gorno Vranovci and other hospitals. The hospital was moved on November 15, 1944, two days after the liberation of Skopje, to the same facilities where there had been a military hospital before the Balkan wars (Fig. 1), well known among the population as the "Crescent" hospital [2].

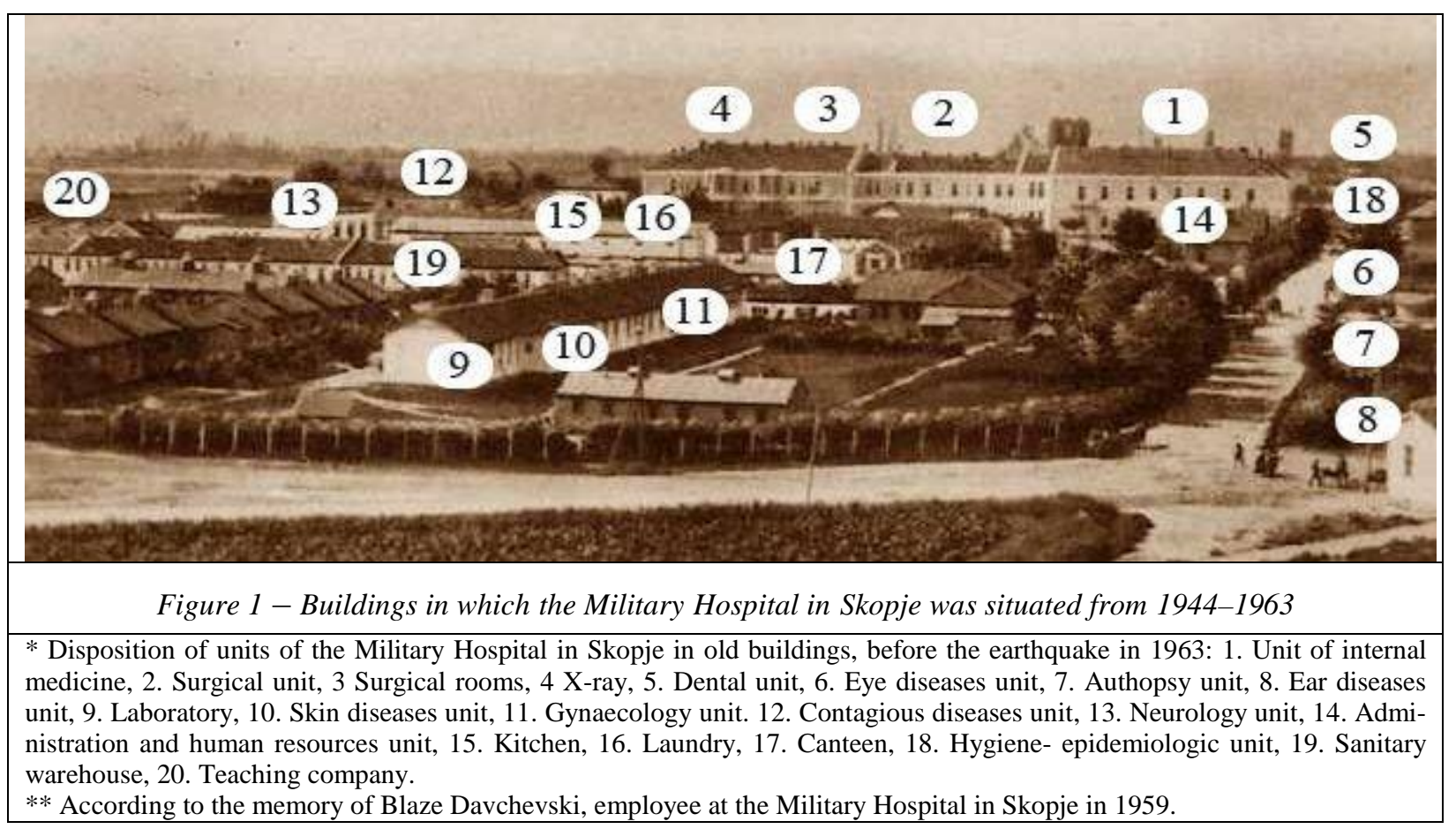

In March 1945 the Yugoslav Army was formed [3]. Since then the hospital has functioned as the Military Hospital in Skopje, designed primarily for the needs of the 5th Army. Within the military sanitation service, the hospital developed, was equipped and worked with the dynamics of an evolved army. The beginning was tough. The accommodation was in poor conditions, in buildings constructed in the Ottoman Empire and completely worn out. There were too many sick and wounded, from all over the territory of R. Macedonia, southern part of Serbia and Kosovo. There were few personnel and equipment was worn and incomplete. A strong will and enthusiasm were necessary for all those factors to be brought to a tolerable condition for work to be possible. Since its formation the hospital had fully cared for the wounded and sick soldiers, and remained open to the population. The rebuilding of the ruined country was followed by the reorganization of the health system. The civilian health service became separated from the military sanitation service. Demobilization led to a reduction of military medical personnel, and simultaneously the hospital beds network was down-sized in real measures for the real needs of military sanitation. The staffing problem was emphasized. There was a tendency for the military sanitation service to withhold the good 
specialists. Thus, the Military Hospital in Skopje, by hiring experienced personnel, could respond to its tasks in the post-war period. Prevention, treatment, education of staff and research work had been the areas of work of the Military Hospital since its inception, in cooperation and with the professional assistance of the troops' sanitation service $[4,5]$. Cooperation with the civil health services was a necessity, especially in actions for improving of epidemiological situation in the territory - intense combat of infectious diseases, primarily malaria, typhus abdominalis and typhus exantematicus, and in mass actions for health education.

In the initial period there were up to 800 hospital beds in the hospital, and later that figure changed. Besides treating inpatients, medical staff at the hospital were engaged in the work of the specialized offices of the polyclinic, too. These were assessing the suitability of recruits for service in the army, and medical specialists with the highest expertise were engaged for these tasks [6].

Initial periods in the work of the Military Hospital-Skopje

There are two initial periods in the work of the Skopje Military Hospital:

The first period, from mid-November 1944 to the end of the war in May 1945. It can be said this was a period of military actions with many sick and wounded patients, a lack of expert personnel and difficulties in providing materials, regardless of the major efforts made by the war-torn and ruined country.

The second period, from May 1945 to July 1963, featured tidier conditions although there were still traces of war, with diseases varying from military outbreaks, diseases which are characteristic of under-nutrition, reduced resistance of the organism and the like. Health facilities were repaired and adapted. More modern equipment and medical products were purchased. The poor hygienic-epidemiological situation resulted in infectious diseases, but with well-defined measures the situation gradually improved. Conditions existed within the hospital for the peacetime organization of work with the necessary specialist departments, and with a complete ambulatory-polyclinic service. At the beginning there were divisional hospitals, hence the capacity of the hospital was exploited at a lower level. Until 1963 the number of military personnel and their family members admitted to the hospital amounted up to 7,000 per year, and the number of hospital days was nearly 200,000 , with an average length of stay of over 20 days. Initially, civilians were treated in small numbers. From the same beginning point, staff were directed to further professional development and civilian doctors were accepted for medical internship, as well as military doctors for training and specializations. Great attention was paid to the regular vocational training in performing complex tasks. A library with professional literature was established. Following 1955, more civilians were treated. An afternoon service with a special status for the treatment of civilian patients only commenced work. From the organizational point of view, the general medical service was separated from the specialists services in all medical branches. With this solution the doctors in the Military Hospital were motivated, in their spare time, to work with civilian patients in the hospital. Civilian patients changed the previous casuistry and allowed the education of military doctors in other "more interesting" manifestations of diseases. In 1962, 2,571 civilian patients were admitted to hospital with 44,339 hospital days, and an average of 17 days of hospital stay per patient.

\section{Role of the Military Hospital during the catastrophic earthquake in Skopje, 1963}

Medical services in Skopje just before the earthquake in 1963 consisted of 17 inpatient health care institutions with a total of 2,400 hospital beds, 60 other healthcare facilities, 289 physicians and 478 nursing staff [7].

The devastating earthquake in Skopje happened on July 26, 1963, and 1070 people died. The number of seriously injured was 1087 people treated in hospitals, of whom more than half (618) were treated at the Military Hospital in terrain conditions. There were 2030 less seriously injured registered, who were treated with first aid and outpatient treatment. Of the seriously wounded, 33 people died in the hospital [8].

Organization of care for injured persons 
Eight months before the devastating earthquake, on November 16, 1962, Skopje was affected by a major flood. Despite this, in 1963, according to Dr. Isidor Papo, surgeon at VMA, Belgrade [9], there was no overall plan for disaster response by all the public services in the city, there was no solid concept for organizing health care to solve the problems of a mass disaster. There was no plan for the level of preparedness of the health and other services to solve problems in a mass disaster, and deal quickly and effectively with such a situation. There are no data as to whether the capacity of health personnel, equipment, doctrines, rules etc. for solving problems in a mass disaster were at the required level. There are no data about the existence of a concept for organizing surgical care in case of mass injuries, to check the real situation and the organization and operation of the health services on site (terrain conditions).

In the first hours after the earthquake, the Republican Headquarters for the removal of the consequences was formed. At the Headquarters there was a representative of the military sanitation, too. The Republic Secretary of Health had gained authorization to give all the necessary orders without prior agreement from the National Headquarters or the Executive Council of R. Macedonia. Chief of the health sanitation service of the Skopje military district, Dr. Methodije Dimitrijevic, had the widest powers from the command, based on its own assessment of the situation on the spot, and was authorized to issue the necessary orders and to organize specific activities. Such a positive solution provided speed and efficiency in organizing care for the wounded and the implementation of other measures.

The catastrophic earthquake in Skopje, which occurred on July 26, 1963, at 5.17 a.m., significantly damaged the facilities of the Skopje Military Hospital, the Outpatient unit, the army sanitation warehouse, and the Hygienic-epidemiological service in Skopje (HEO). Only minor ancillary facilities remained intact. The building of the Skopje Military Pharmacy, which was at a distance of $2.5 \mathrm{~km}$. downtown, was damaged too. The military health sanitation personnel were available in less than an hour, and together with crews on duty they evacuated all the inpatients outdoors in the park of the hospital. Immediately, the hospital staff began to organize work in terrain conditions. The equipment and medicines were carefully placed outside the hospital. After triage of the existing patients, many of them were discharged in order to relieve the hospital capacities. Shortly, surgical interventions in terrain conditions were exercised. In coordination with the health service and the Headquarters, some terrain / field medical stations for providing medical assistance to the wounded were formed, as follows:

1. In the round of the Military Hospital terrain military hospital with departments and offices, outpatient clinic, shelter, triage stage, medical warehouse and HEO were formed (Fig. 2). The bacteriological laboratory began work on July 28, 1963 [10].

2. The round of university clinics - reception point, terrain stationery, sanitary warehouse etc;

3. The round of the City Hospital - reception point with stationery and the medical warehouse.

The next day, July 27, 1963, two military sanitation points were created, with two surgical teams from the Military Medical Academy (VMA) in Belgrade: reception station, with a surgeon at the old Skopje airport and a surgical checkpoint in the municipality Karposh. The station at the airport had the role of triage stage. Here, surgical preparation of the seriously wounded was performed to preparing them for air evacuation. Professional staff embraced aid and medical supplies provided for the health service in Skopje [11-14].

Immediately after the earthquake, military emergency teams from garrisons in Macedonia arrived, consisting of a doctor, nurse, paramedic and driver, with a sanitary vehicle, equipment and medical kits. Removal of the ruins was also performed.

In the early days, when there was a large arrival of medical teams and medical aid in Skopje, because of poor organization, forced evacuation of the wounded was conducted to other cities without preparations for evacuation, and this resulted in various difficulties and complications. The Yugoslav Military Air Force and the Civil aviation company, JAT, organized an "air bridge" for the fast arrival of professional staff, equipment and facilities, as well as 
evacuation of the patients with the most difficult injuries.

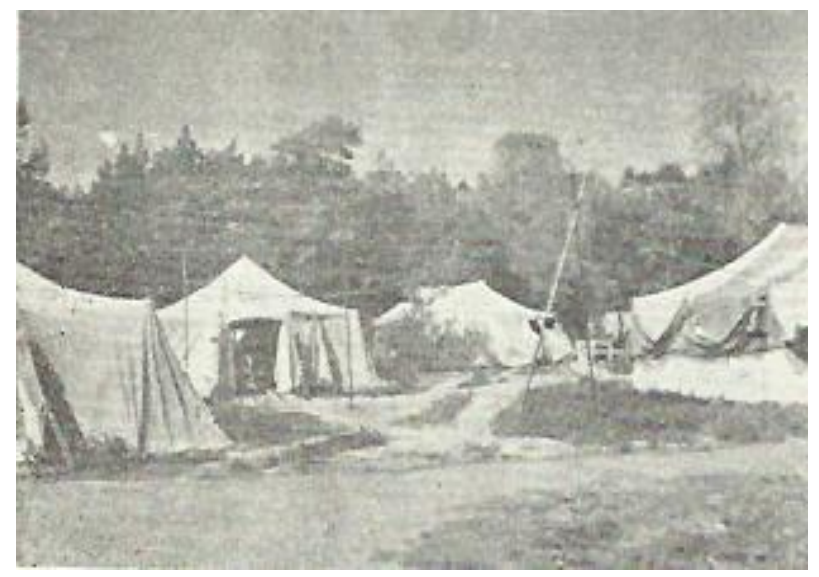

Figure 2 - Military Hospital in terrain conditions, in the park of the wrecked hospital, 1963

In 1963 the President of SFR Yugoslavia rewarded the Skopje Military Hospital with the Order of Merit for the people with a golden star for special commitment and extraordinary efforts during the earthquake. The Hospital received a special recognition from the City of Skopje and some individuals from the staff were honoured and rewarded with adequate appreciation.

\section{Military sanitation warehouse and medical supply during the earthquake in Skopje, 1963}

The devastating earthquake in 1963 damaged military medical facilities in Skopje. Buildings, equipment and consumable materials were destroyed. This raised the need to adapt the work to terrain conditions. Sanitary materials, appliances and equipment were dragged from destroyed buildings and placed in operation. Sanitary materials were held in the army sanitation warehouse in Skopje for current needs and as a military reserve, then for the convenience of the departmental pharmacies of the Military Hospital and Military pharmacy. There was an increased demand for the issue of supplies and drugs, while improvised documents were used. Among civilian structures for medical supply the most powerful was the pharmaceutical company Replek, which was not too badly damaged by the earthquake [15-17].

After the earthquake and up to 1971 Skopje Military Hospital continued to work in especially difficult circumstances and makes- hift facilities. This was a specific period in the work of the Military Hospital. The hospital was practically reduced to the most essential extent, staff were redistributed across the country, a lot of equipment and facilities were destroyed. After the earthquake in 1963 the hospital had only 150 hospital beds. Due to limited accommodation options, lack of staff and poor material conditions, the workload was significantly reduced. In 1964, there were about 3,200 military contributors treated in the hospital, with 47,533 hospital days and an average length of treatment of about 14 days. The number of civilians treated in hospital became symbolic, only 131 people, with 2,426 hospital days and an average length of 18 days' treatment. The outpatient ambulance service was well organized to satisfy the healthcare needs of military personnel. The outpatient office for civilians as a separate organization ceased to function, and a small number of civilians were examined and treated within normal working hours.

Such a situation could not persist for long, and over the years the number of hospital beds was gradually increased, the necessary equipment was provided, and the most attention was committed to schooling and the continuous education of the staff. The period between 1963 and 1971 was used for rational planning, in addition to performing basic tasks. The most important was planning for the building and equipping a new facility for the Skopje Military Hospital.

In the years that preceded the moving into the new hospital (1971) the number of military insured treated in the hospital increased to 5,000 per year, with 75,000 hospital days and an average of 15 days of treatment. The number of civilians treated in the hospital was about 1,440, with 23,000 hospital days and an average of 16 days of treatment in hospital [6].

\section{New facility for a modern Skopje Military Hospital}

During the disastrous earthquake in Skopje, among other buildings, the Military Hospital was almost completely destroyed. In 1964, a location was obtained to build a new, modern facility for the military hospital. The building plans dimensioned the object for optimal provision of hospital care for military be- 
neficiaries and the citizens of Skopje and other cities in Macedonia and further afield (Fig. 3).

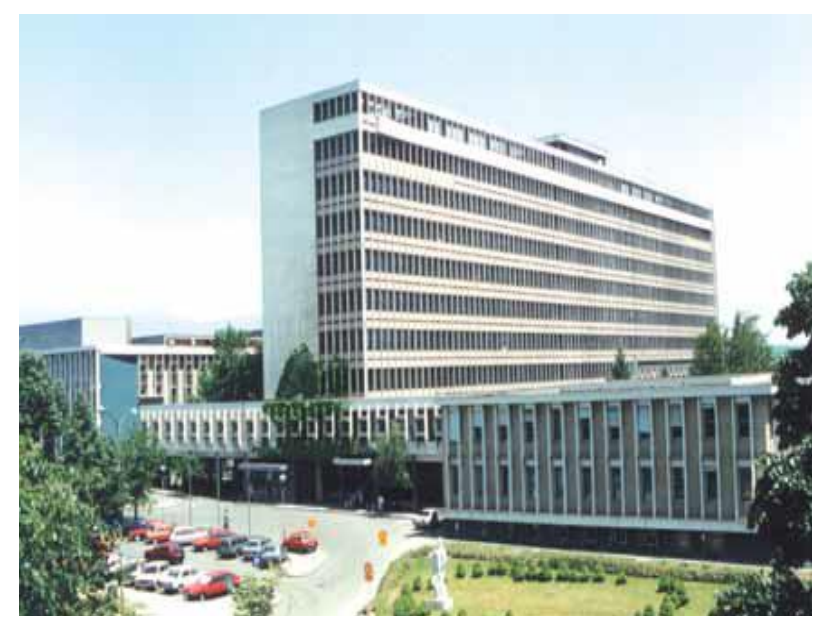

Figure 3 - The new complex of buildings of the Skopje Military Hospital, shown in use in 1971

Technical and functional characteristics of the buildings in the military medical facilities complex - a new "Military Hospital in Skopje"

The first investment programme to build a new military hospital in Skopje was made back in 1955, but even after the devastating earthquake in 1963 it approval for construction had definitely been delivered. A Working group was constituted to make a preliminary design for the building and for equipping the new hospital. The funds for construction, in a balance of $50 \%: 50 \%$, were provided by the Federal Secretariat for the National Defence of Yugoslavia and the Fund for the Reconstruction of Skopje. The project provided a single building complex for several medical institutions, including: Military hospital, Hygieneepidemiological unit, Garrison outpatient ambulance and Military pharmacy. The new facility marked a new period in the work of the Skopje Military Hospital. The complex was built on an area of 9 hectares, with 3 hectares of green space and $60,000 \mathrm{~m}^{2}$ of internal usable space with 3,000 rooms and 520 hospital beds. Staff were duly prepared to work with the most modern equipment in the most advanced facilities at the time. Outside the single-block system but within the circle of the complex were: a facility for teaching hospital unit, garage, covered parking and a sports field. In 1974 the facility for teaching unit was turned into a Recruitment centre.

Organizationally, as a separate sanitary facility, the Military Hospital occupied most of the complex. There were standard specialist departments and outpatient units available, in which hospital treatment and polyclinic specialist consultancy services were provided through specialist offices, outpatient clinics and diagnostic departments. The hospital treated patients from various insurance categories: military, civilian, foreign military and civilian personnel, and diplomats and their families. Statistically, over the years 1991 to 2009 , it was registered that more than 100,000 visits annually were made in the polyclinic specialist consultative section, and an average of 10,000 patients were admitted to the hospital departments a year.

From the construction point of view the hospital has several parts: a stationary block, polyclinic block, administrative and social-cultural department, economic-technical block and military pharmacy with a galenical laboratory.

1. The stationary block has 9 floors, with 15 hospital units of 30 beds each, in which hospital departments are placed for inpatient treatment: surgical departments with a unit for burns, the internal medicine departments with a unit for internist intensive-cardiac care, neuro-psychiatry, a department for skin and venereal diseases, eye diseases, diseases of the ear, nose and throat, infectious diseases and a department of physical therapy and rehabilitation. This section had 465 hospital beds (most were within the surgical and internal medicine departments).

The surgical departments were: for digestive surgery, urology, orthopedics and traumatology, plastic surgery and vascular surgery. Modern operating theatres were placed in a separate annex. Emergency cases are operated on in the halls for urgent surgery. For scientific experimental surgery (at one time) there were a specially equipped surgery room and a small farm with experimental animals. The department for the treatment of burns is separate, with operating room and an area for complete isolation in aseptic conditions during treatment.

The central sterilization department is unique to the hospital.

The internal medicine departments are: for gastroenterohepatology, cardiology, pulmo- 
logy and nephrology (haemodialysis provision began in 1981). Here there is a unit for coronary intensive care with 24 hour monitoring.

The neuropsychiatric departments are for neurology and psychiatric patients.

The eye department has a stationary part and an ophthalmic office for orthoptics and strabology for advanced outpatient treatment of eye diseases.

There is a separate department for skin and venereal diseases.

The department of infectious diseases within the stationary block has a separate entrance from inside the block and an additional independent entrance for external patients with infectious diseases. It has a special internal structure, with all modern requirements for the care and treatment of infectious patients, and disinfection, and communication of the sick with visitors is through complete isolation.

The Department for ear, nose and throat had cutting-edge generation apparatus for diagnostics and therapy at that time. A specially equipped audiology cabinet belongs to this department.

A special architectural unit for emergency medical service was established, for 24 hour acceptance of emergency the acutely ill and injury cases with endangered vital functions, for implementing resuscitation at the level of advanced life support with an emergency internist's care and a surgical room for urgent interventions, resuscitation and daily hospital, surgery and surgical plasterintg.

At certain periods of time the Military Hospital has had different total numbers of employees. The maximum number in one period was about 1000 people. Most employees were health workers able to apply almost all modern medical interventions, procedures and tests for medical aid, and in some specialist branches super-specialist medical care was provided. The hospital operated medical commissions for the sanitation service needs. Nearly a fifth of the employees in this complex were administrative and logistical support and other supporting services that enabled a continuous 24 hour operation.

2. The polyclinic block houses the cabinets of all the specialized branches of medicine, various diagnostic facilities, dental departments, the x-ray department, a central clini- cal laboratory, a station for a blood transfusion, a department of physical therapy and hydrotherapy pool, etc. In addition to this block two other medical facilities are housed: the hygiene-epidemiological unit and the Garrison outpatient clinic (with 70 beds). The following diagnostic facilities are included in the polyclinic block: echocardiography, echotomography, holter diagnostics, upper and lower endoscopy, bronchoscopy, cystoscopy, audiometry, electroencephalography, functional diagnosis of heart and lung diseases, electromyography, allergology and more. There is also a gynaecological cabinet equipped for smaller gynecological interventions.

Dental offices (located in the polyclinic block) are composed of units for diseases of the teeth and mouth, orthodontics, oral surgery, pediatric dentistry and a prosthetics department with dental techniques.

The department of roentgenology/radiology within the polyclinic block has specially built safe rooms equipped with modern equipment. Here standard and more complex diagnostic procedures such as arteriography and computed tomography of the whole body are implemented.

The central clinical laboratory has been equipped with modern automated equipment for the simultaneous examination of more than 30 biochemical analyses. In a relatively short time it is possible to examine various types of biological material, and the results are usually received the same day.

The department of transfusion works collecting blood from voluntary donors, primarily with field work in military units and troops, and other donors. The collected blood is processed and distributed to certain departments of the Military Hospital, and if necessary to other health facilities in Skopje and other cities. Here, haematologic diseases are diagnosed and treated, too.

The complex of diagnostic units has a unit for the application of radioisotopes.

The department of pathology, pathohistology and forensic medicine, with a separate mortuary for the dead, occasionally changed its initial location in the complex.

Specific parts of the block (with separate entrances) are the cabinet for paediatrics and the antituberculosis dispensary (ATD). 
The admission unit exercises the receipt of sick for hospital treatment, opening history record files and transporting patients to the relevant departments, keeping statistics on inpatients, and the storage of archival material in the "bunker" for long-term archiving of the histories of patients, protocols, health cards and other documents.

3. The administrative and social-cultural department in the complex is a separate annex to the stationary block, connected to the large block by a corridor. The administrative area houses managerial and administrative offices, the library, classrooms and a cinema hall. There is a room for entertainment and friendship, and a fitness room.

4. The economic-technical block has more functional units, such as the kitchen, laundry room, boiler room, diesel power plant, station for medical gas, technical workshops and warehouses. This block has a separate entrance. Through the large number of elevators (total 21) it is possible to provide separate supplies of food, clean and dirty laundry, transportation for the staff, patients and others. Automatic motion is presented to the max and all plants are controlled by two command centres. The hospital has its own great telephone central command with lines for connection to each room, its own station for a public address system, and at first a pager system was functioning for emergency reporting to the duty station. Stationary patients and personnel on duty receive food from the central kitchen by the "tablet system", individually determined for each patient. There are two open type restaurants within the hospital. The fleet consists of more sanitary disposal and other vehicles, including a fire service, too. The building has its own heating and its own laundry. Initially the hospital had a photo-and-movie laboratory. The technical part included a furnace - incelerator (a small crematorium for organic waste). A gardener takes care for the park around the hospital.

5. The military pharmacy with galenical laboratory is situated between the stationary part and the polyclinic and serves the stationary (hospital pharmacy) and patients through external officio. Besides the storage rooms, a specially equipped galenic laboratory produces, keeps and distributes galenic products.
Starting with the work of the Military Hospital in Skopje in the new facility, 1971

Skopje Military Hospital actually started functioning in the new facility on 1 July, 1971. At that time it was recognized as the most modern and functional health facility in the Balkan Region. In fact, Skopje Military Hospital with its new building is a precious health facility and real pearl within the overall health system in R. Macedonia. Moving into the new building was carried out in stages. In a relatively short time the planned features/ functions had been established without disrupting the continuity of hospital treatment during the move from the old to the new facility. No opening ceremony was officially done because the hospital had already worked for months (although in stages and in parts), and by the end of 1971 its facilities were $94 \%$ in use [18]. In order to promote facilities and conditions for the public only the formal release of the complex was carried out on December 18, 1971. Military and civilian doctors and representatives of the highest social-political organizations of R. Macedonia and the City of Skopje were invited. The new modern medical complex in Skopje was shown to the audience, with its excellent location, large parking lots and road connectivity. A landing area in the park with a heliport, with opportunities for night landing, was also reviewed. It was presented as the unity of the health system through the complex of health care facilities to provide comprehensive health care, including general health care through the Military outpatient clinic, specialist-consultative health care through the Specialist polyclinic, hospital care through the stationary block of the Military Hospital, dispensing drugs, producing galenical preparations and sanitary supplies through the Military Pharmacy, and specialized preventive medical care through the Hygienicepidemiological unit.

After moving and making all units function, the hospital was used maximally. Although it was a military institution, it was an institution of the city of Skopje and R. Macedonia. This means that a significant portion of its capacity is also used for the needs of the public health service and the general population. From that same starting point, the city of Skopje and 
the country had officially been offered the use of some 200 hospital beds and the outpatient specialist services of the polyclinic. The hospital constituted a major contribution to the health system for the region that gravitates towards it (SR Macedonia, Kosovo and southern part of Serbia). Since 1975 around 50\% of the capacity has been used for the health care needs of civilians, and a special service has been organized by a second shift at work. According to statistical data from the then trustee Dr. Dusan Karanovski [6], the ratio of treated military personnel and civilians was as follows: in 1975 the number of military beneficiaries admitted for hospital treatment was 3,990, with 87,234 hospital days and an average length of stay of 15.5 days, while the civilian patients admitted to hospital were 3,491 , with 64,435 hospital days and an average hospital stay of about 18 days. Dr. Karanovski said that for a period of 15 years there was a total of 162,231 patients treated in the hospital (of whom 30,048 or $18.5 \%$ were civilians), with $3,042,685$ hospital days (of which 514,514 or $17 \%$ were civilian) with an average length of stay of 17.24 days. The utilization of the hospital capacities was initially $61.6 \%$ and in 1974 was $89.4 \%$. For a period of fifteen years the cabinets of the polyclinic carried out $1,825,650$ specialist examinations in total, of which $1,471,140$ or $80.6 \%$ were of the military contributors, and 354,853 or $19.4 \%$ were civilian insured. The number of employees in 1974 was around 600 [6].

\section{Skopje Military Hospital in the independent Republic of Macedonia, in the 1990s}

After the independence of R. Macedonia in 1991, and the formation of the Army of R. Macedonia in 1992, a question for reform of the military health facilities in the country was asked, just as in other republics and military hospitals on the territory of former Yugoslavia. Considering the need to implement rational financial operations at the Military Hospital, there were suggestions that it should be transformed into a civilian hospital and be taken over by the Ministry of Health of R. Macedonia. During the 1990s Skopje Military Hospital continued to operate in the existing facility, built in 1971. The hospital, with its $1,000 \mathrm{em}-$ ployees and 465 beds, was sized for the health care needs of former members of the army on the territory of R. Macedonia, Kosovo and southern part of Serbia, and with some capacities for the civilian population. According to the process for establishing a small, mobile and efficient modern army in R. Macedonia, there was a need to transform the Military Hospital and to establish a new military medical facility that would meet the needs and challenges of the 21 st century and the mission ahead.

In April 1992 a new medical facility was formed in the Ministry of Defense of R. Macedonia and the Army of R. Macedonia the "Centre for Military Health Care Facilities." Within the Centre were included existing health sanitary facilities: the Military Hospital, the Institute for Preventive Medical Care, the Military Ambulance and Military Pharmacy. The Centre, as supreme military health institution in a unique structure, integrated the following forms of health care: primary health care, specialistconsultative and hospital health care, and specialized preventive medical care. During its existence and work this military medical complex has contributed greatly to the health care of the entire population in R. Macedonia. In addition, the Centre has provided health care for the special forces of the UN - UNPROFOR (at some stage), foreign citizens, diplomatic staff and others. Many renowned experts have worked in the Military Hospital. As devoted professionals and enthusiasts, with extraordinary commitment and care for the patients, they have affirmed themselves, military sanitation, the hospital and the army. This applies to the military structure and the civilian employees at the hospital. Many doctors on the professional staff have been engaged in additional areas and activities: academic teaching and research projects and in professional-social activities. Some of them have acquired professional recognition and academic titles from the Faculty of Medicine, the Faculty of Dentistry and the Military Academy in Skopje, have participated in congresses, symposia, professional meetings and have published articles in national and international journals. Medical staff, especially young doctors and specialists, have been sent for long-term professional education, initially to the Military Medical Academy in Belgrade, and then to the Faculty of Medicine in Skopje and abroad. Many professional educational activities and meetings, with practical training 
for medical students and students from nursing schools, medical technicians and internship for doctors on specialization, have been organized in the Military Hospital. A large number of conferences of military doctors, as well as the $15^{\text {th }}$ scientific meeting of microbiologists and epidemiologists and numerous sectional and other meetings of the Macedonian Medical Society (MMS) have been held in the Skopje Military Hospital. Traditionally every year, on the occasion of World Health Day, the seventh of April, MMS organizes a formal meeting of doctors at the Skopje Military Hospital with an introductory lecture on a theme set by WHO, and other appropriate lectures.

In 1975 the hospital was declared a training base for the Faculty of Medicine and Faculty of Dentistry in Skopje [19-21], and from 1993 for the Military Academy of ARM, for undergraduate and postgraduate studies and specializations. The hospital is training base for conducting mandatory clinical internships for trainees of the Faculty of Medicine and Faculty of Dentistry and other types of training, development and various forms of continuing medical education. The staff of the military health institutions have participated in several international exercises and missions. For completion of regular and continuous education of professional staff of these and other institutions and facilities of the Skopje Military Hospital were used; a large library with classrooms, a large movie theater with some 300 seats has often been used to hold conferences, seminars, symposia and other professional meetings of health care workers in R. Macedonia.

Health sanitation staff of the Skopje Military Hospital edited and contributed in issuing periodical publications. According to Dr. Tomislav Miladinovic [22], the Medical Bulletin started to be issued in 1952, and in 1957/58 was printed as the Newsletter of Skopje Military Hospital. From 1959-64 it was published as the Newsletter of the Skopje Army and, after a pause, again started publication from 1978 to 1987 , entitled MEDICAL BULLETIN - journal of doctors and pharmacists of Skopje military district [22].

\section{Transformation of the Military Hospital in Skopje after 2000}

The military hospital had all specialist cabinets and departments, except the cardiosur- gical and neurosurgical specialty. In order to maintain its reputation among citizens and to expand the range of health services provided, on January 19, 2000, a Cardio-surgical department began work, and split off in 2002 to become the Philip II private special hospital for cardiac surgery, continuing to use the space and equipment under concession [23].

The need for the effective and efficient operation of the available military resources in defence induced a need to revise the mission of Skopje Military Hospital. Therefore, on several occasions, different variants for transformation were suggested. There were always plans for a drastic reduction of the facility for use for military health needs and an appropriate number of employees, as well as an option to transfer it to being the responsibility of the Ministry of Health.

In March 2008, without transformation, the Military Hospital, with 600 employees, was transferred into the composition of the Ministry of Defense as "Military Health Service - Military Hospital", tasked with cutting the number of employees to 450 people.

With the downsizing the Army of R. Macedonia, and in accordance with NATO standards, the need evolved for further reducing and changing the mission of the Military Hospital. After detailed analysis of the existing facilities, personnel, military population for health support and care and economic feasibility, on January 1st, 2010, a real transformation of the Skopje Military Hospital was made, where it was discharged and was followed by two institutions:

- Public health institution (PHI) Eighth September City General Hospital, and

- Military medical centre with $142 \mathrm{emp}$ loyees.

\section{Conclusion}

This article is dedicated to the $70^{\text {th }}$ anniversary of the date of the establishment of Skopje Military Hospital, a hospital which continued the high tradition of the hospital of the People's Liberation Army and Partisan Detachments of Macedonia. For the whole period of its existence, from November 15, 1944 to January 1, 2010, Skopje Military Hospital was one of the key institutions in the integrated health system of R. Macedonia, which provided hi- 
ghly professional secondary specialist-consultative and hospital health care for members of the military and civilian population until its final transformation in 2010.

During its existence, starting from the most difficult periods of the war, postwar renewal and state building, as well as during the natural disasters and epidemics, many times the Skopje Military Hospital- has proven the highly professional and selflessly devoted work of the military and other medical personnel in providing health care for members of the army and the people from what ensued.

\section{Limitations of the study}

Some of the available sources of information are poor and do not have sufficiently precise data. Many of the archive materials were taken during the displacement of the Yugoslav People's Army from R. Macedonia, under whose command the Skopje Military Hospital was till 1992, and deposited in the archives of R. Serbia. Also, when the Skopje Military Hospital was revoked, in 2010, some of the documents in the archive and in the hospital library became inaccessible. However, the data and information from various alternative sources and published literature, together with the personal experiences and memories of the authors, provide a clear picture of the different stages in its development and activities, as well as the significant role of the Military Hospital in Skopje in the past 70 years for the Army and for the citizens of R. Macedonia.

\section{Trustees of the Military Hospital in Skopje}

According to the available data there are 11 trustees who managed the Skopje Military Hospital in certain periods from its establishment in 1944 to its transformation on 01.01.2010 (Fig. 4).

\section{REFERENCES}

1. Kamcevski Gj. Medical service of the Peoples Liberation Army of Macedonia. Vojnosanitetski zavod, Belgrade, 1971.

2. Kamcevski $\mathrm{Gj}$. Health sanitary service in the final operations of the Peoples Liberation Army of Mace- donia. In: Đondovic R, editor-in-chief. The origin and development of the medical service in the armed forces of the national liberation movements in Bosnia and Herzegovina, Montenegro, Croatia and Macedonia [In Serbian]. The second book, Belgrade, 1989: 447-66.

3. Government of Democratic Federal Yugoslavia. The decision on the Yugoslav Army - Transforming People's Liberation Army in the Yugoslav Army, March 1, 1945. Official Gazzette of DFY, no. 9, 1945.

4. Presidium of ASNOM. Decision for establishing the state health service. Acts of the Presidium of ASNOM. Official Gazette of R. Macedonia, Number 1 First Year (1944), Skopje, 1944.

5. Konstantinov M. Development of medicine in Macedonia. [In Macedonian]. In: Lazarevski M., Editor-inChief. Faculty of Medicine in Skopje 1947-1987. Faculty of Medicine, Ss Cyril and Methodius University, Skopje. Skopje, 1987: 167-82.

6. Karanovski D. Thirty years of existence of the Military Hospital in Skopje. Vojnosanit. Pregled. 1975; 32(1): 3-7.

7. Sivic A. Skopje evacuation-receiver and some organizational issues. Vojnosanit. Pregled. 1964; 7-8: 45662.

8. Funtek M. Some experiences from the organization of health care in the devastated Skopje. Vojnosanit. Pregled. 1964; 7-8: 448-55.

9. Papo I. Skopje disaster - a lesson and a warning. Vojnosanit. Pregled. 1964; 7-8: 439-45.

10. Sokolovski B. Work of the bacteriological laboratories after the devastating earthquake in Skopje. Vojnosanit. Pregled. 1964; 7-8: 499-501.

11. Bervar M, Jankulovski A, Atanasijevic T, Jeftic S. Mobile surgical team of the Military Medical Academy in Skopje disaster. Vojnosanit. Pregled. 1964; 7-8: 507-9.

12. Predanic E, Kamcevski Gj. Organization, operation and problems of surgical services of the Skopje military health care after the devastating earthquake. Vojnosanit. Pregled. 1964; 7-8: 468-75.

13. Predanic E, Kamcevski Gj. Medical issues of the Skopje disaster - general, anatomical and clinical characteristics of injuries and their treatment - Analysis and Comment about 618 injuries cared for in the surgical field hospital in Skopje in the period 2628.07.1963. Vojnosanit. Pregled. 1964; 7-8: 476-80.

14. Gjorgjevic D, Miladinovic T, Arsic B. Preventive and anti-epidemic work in Skopje garrison after the devastating earthquake. Vojnosanit. Pregled. 1964; 7-8: 492-5.

15. Gjogjevic Z. On some problems of medical supplies in Skopje disaster. Vojnosanit. Pregled. 1964; 7-8: 463-7.

16. Hranilovic A. Medical supply in the catastrophic earthquake in Skopje, 1963. Vojnosanit. Pregled. 1964, 1: 27-9.

17. Veljanovska D, Hranilovic A, Surovi Z. Some experiences from the work of military pharmacy after the 
earthquake in Skopje, with special emphasis on the development and testing of parenteral solutions. Vojnosanit. Pregled. 1965; 5: 306-7.

18. Dimitrijevic M. New Military Hospital in Skopje. Vojnosanit. Pregled. 1972; 2: 82-3.

19. Nikodijevic B, Velkov K, Chaparoski R, Glavas E. Surgical department at the Military Hospital in Skopje. In: Lazarevski M, editor. Faculty of Medicine in Skopje 1947-1987. Faculty of Medicine in Skopje. 1987: 372-4.

20. Nikodijevic B, Velkov K, Chaparoski R, Glavas E. Otorhinolaringology service at the Military Hospital in Skopje. In: Lazarevski M, editor. Faculty of Medicine in Skopje 1947-1987. Faculty of Medicine in Skopje. 1987: 375.

21. Nikodijevikj B, Velkov K, Chaparoski R, Glavas E. Center of military health institutions. In: Lazarevski M, editor. Faculty of Medicine in Skopje 1947-1987. Faculty of Medicine in Skopje. 1987: 132-3.

22. Miladinovic T. Medical service on the territory of the SR Macedonia 1941-1981. Medical Bulletin. 1982; 1-2: 19-36.

23. Ponjavic S. Military hospital and military sanitation. In: Ristovski B, editor-in-chief. Macedonian Encyclopedia, Part I. The Macedonian Academy of Sciences and Arts, Skopje. 2009: 303-4.

Резиме

\section{, 1944-2014}

$\begin{array}{lrr}\text { ончо } & \text { онев } \\ \text { ндреј } & \text { умовский } & \text { лигоров }\end{array}$

${ }^{1}$ Институт за социјална медицина, Медицински факултет, Универзитет „Св. Кирил и Методиј“, Скопје, Р. Македонија

${ }^{2}$ Пензионер, самостоен истражувач

ел: Да се прикажат фазите и активностите во периодот на постоење и работа на Boената болница во Скопје, од формирањето во 1944 година до нејзиното трансформирање на 1 јануари 2010 година. ейоди: Ретроспективна студија базирана на достапни архивски материјали, енциклопедии и други извори на информации и преглед на релевантната литература, како и лични искуства, опсервации и сеќавања на авторите и на други лица.

езулй $\bar{u} u:$ Во текот на Народноослободителната војна 1941-1945 година, поголемите воени единици формирале болници. На 15 ноември 1944 година болницата на Главниот штаб на НОВ и ПОМ е преселена од с. Горно Врановци, Велешко, во Скопје. Воената болница во Скопје добила статус на постојана болница на 5. Армија, и од 1945 до 1963 година работела во објектот „Полумесечина“. По земјотресот во 1963 година, поради оштетувањето, таа делумно била преселена во болницата во Ниш, а делумно работела во останатите павилјони. Во 1971 година бил предаден во употреба нов воен медицински комплекс, во кој најголемиот дел ѝ припаѓал на Воената болница во Скопје. До 1992 година Воениот санитет бил под команда на тогашната Југословенска народна армија, а потоа бил во надлежност на Министерството за одбрана на Република Македонија. Од 10 април 1992 до 2 јуни 1992 година работел како Воена болница на AРM, потоа како Центар на воени здравствени установи до 26 октомври 2001 година. Потоа повторно го носел името Воена болница на Армијата на Република Македонија до март 2008 година кога преминал во состав на Министерството за одбрана како Служба за воено здравство - Воена болница. На 1 јануари 2010 година Воената болница била преформирана во J3У Градска општа болница „8 Септември“ Скопје и во Воено-медицински центар.

клучок: Воената болница во Скопје во периодот на своето постоење била еден од клучните специјалистичко-консултативни и болнички капацитети во здравствениот систем во Република Македонија за давање здравствена заштита на воените осигуреници и на цивилното население.

лучни зборови: Воена болница, болници, секундарна здравствена заштита, болничко лекување. 

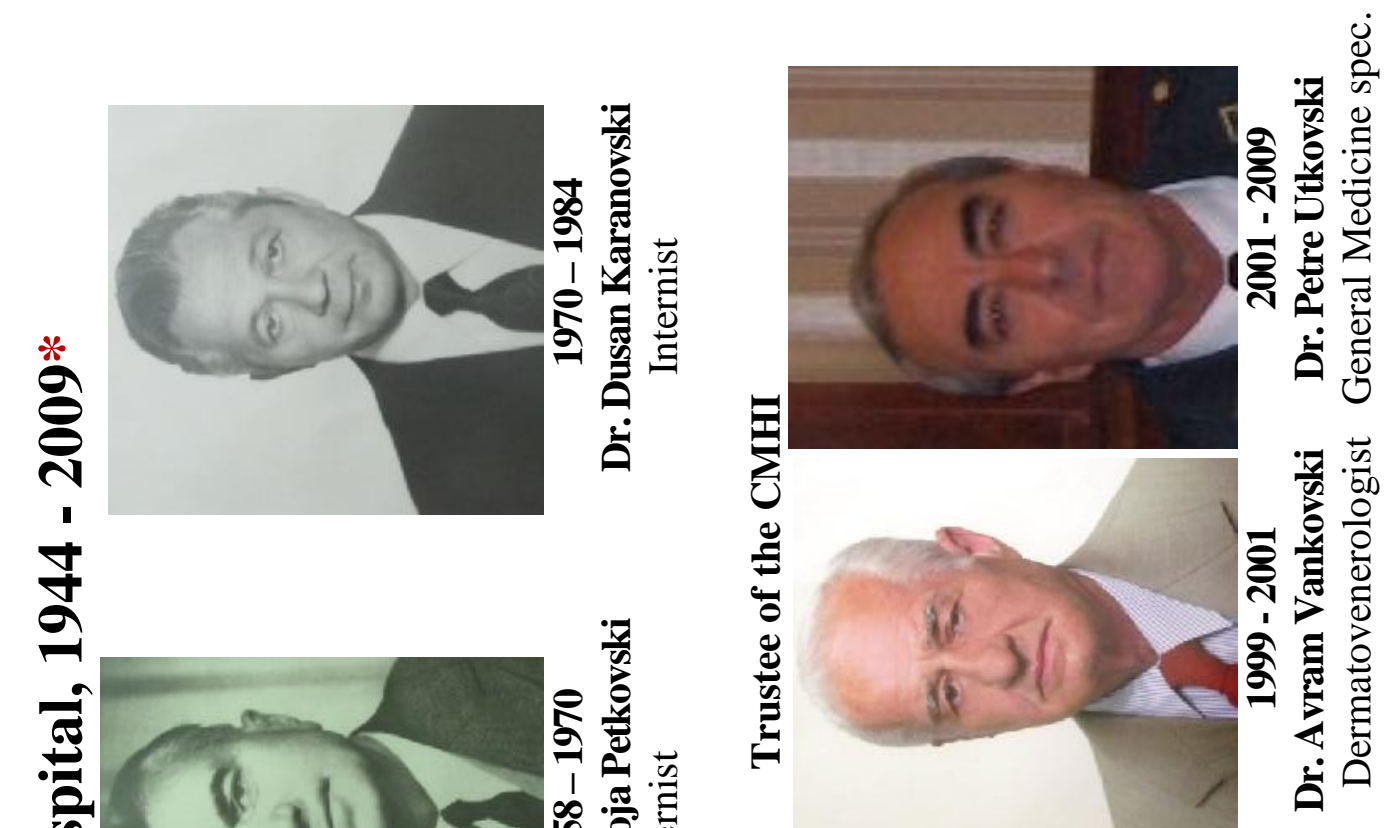

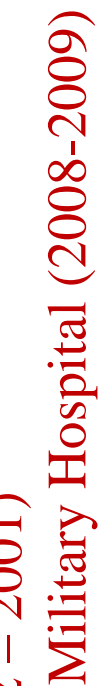
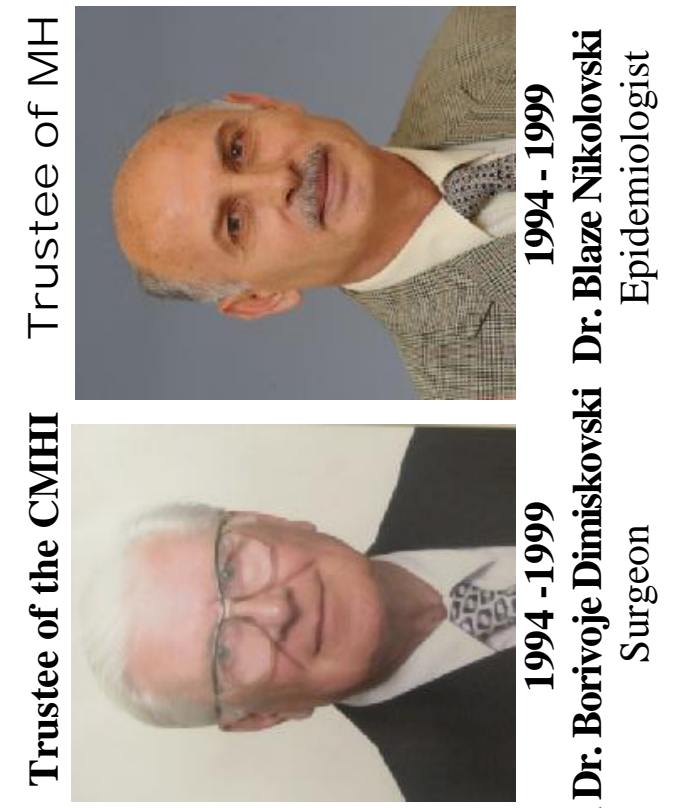

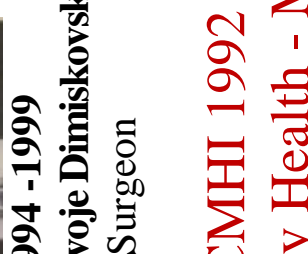
बें

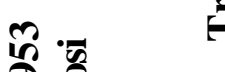

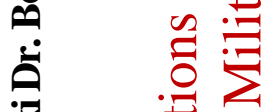

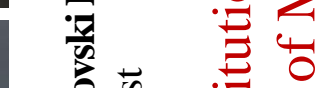

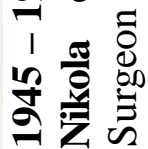
อ̆

范
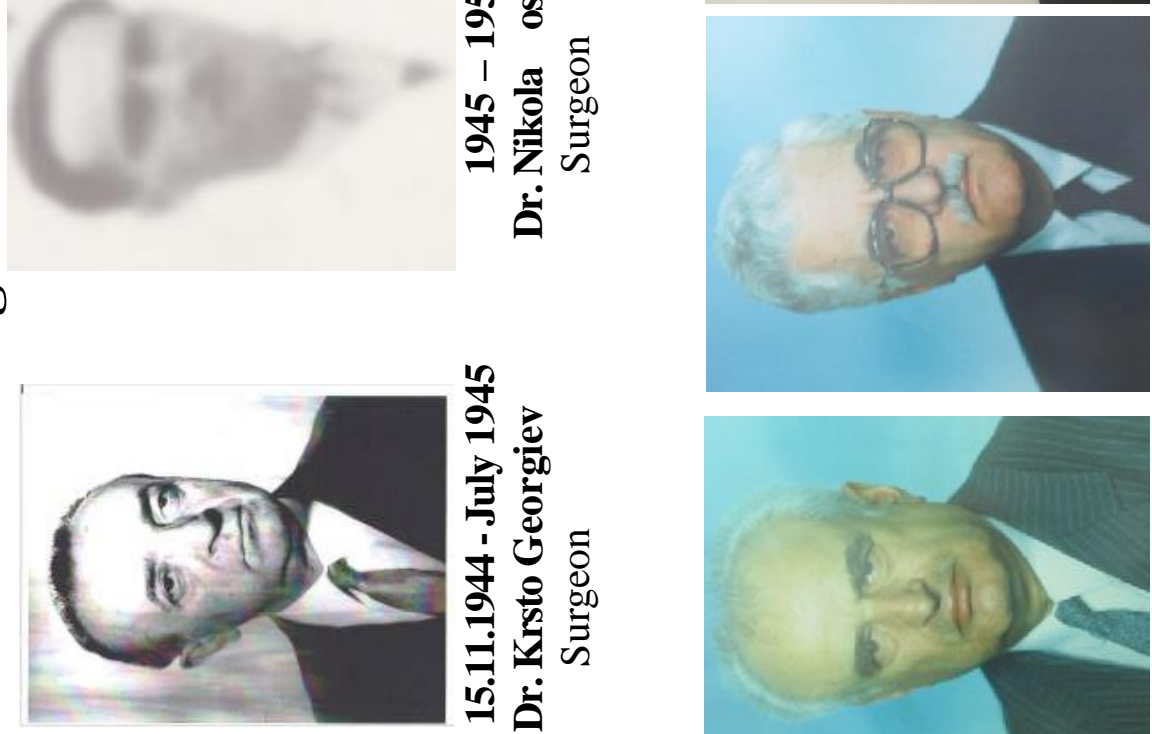

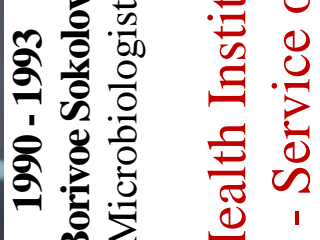
它五 ล ถ气

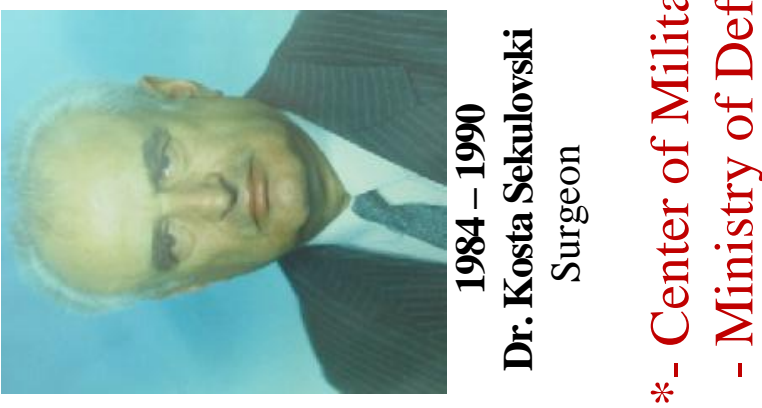

